\title{
Edaphic fauna in a vegetation gradient in the Sete Cidades National Park
}

\author{
L. A. P. L. Nunes ${ }^{a *}$, A. S. F. Araújo ${ }^{a}$, M. M. C. Pessoa ${ }^{a}$, R. S. Sousa ${ }^{a}$, J. D. C. Silva ${ }^{b}$ and \\ C. H. A. Matos-Filho \\ ${ }^{a}$ Laboratório de Qualidade do Solo, Departamento de Engenharia Agrícola e Solos, Centro de Ciências Agrarias, \\ Universidade Federal do Piauí - UFPI, Campus da Socopo, CEP 64049-550, Teresina, PI, Brasil

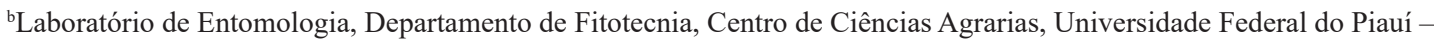 \\ UFPI, Campus da Socopo, CEP 64049-550, Teresina, PI, Brasil \\ *e-mail: luisalfredo@ufpi.edu.br
}

Received: January 5, 2017 - Accepted: August 8, 2017 - Distributed: February 28, 2019

(With 2 Figures)

\begin{abstract}
The vegetation physionomy and cover can show patterns of diversity and composition of the edaphic community, depending on the quantity and quality of litter in a specific habitat. The objective of this study was to evaluate the effect of the vegetation gradient formed by Graminoid Field (GRF), Cerrado Sensu Stricto (CSS), Cerradão (CRD) and Semideciduous Seasonal Forest (SSF) on density, diversity and composition of the edaphic fauna community in two seasons of the year, in the Sete Cidades National Park (Piauí state). For fauna sampling, a total of eight pitfall traps, distanced $10 \mathrm{~m}$, were placed in each area in the central part of each system, where they remained for seven days. In the wet period, there was a tendency to increase the number of individuals as a function of the complexity of the vegetation formation, with the inverse occurring in the dry period. It was verified an environmental variation of the climatic factors temperature and humidity according to the vegetal formation, contributing to a heterogeneous distribution of the fauna. The GRF formation presented a significantly lower value of average richness only in the dry period. Regarding the variables of diversity and uniformity, they did not show drastic variations in relation to the vegetation gradient studied. The dominant groups in the vegetation gradient were Formicidae, Coleoptera, Aranae, Acari and Collembola, with reduction of the number of Coleoptera in the dry season. Principal component analysis (PCA) revealed greater differences in the composition of the communities between the vegetation formations for the rainy season. At this time, the formations SSF and CRD were associated to a greater diversity of invertebrates than CSS and GRF, demonstrating the influence of the vegetation complexity on the soil fauna community.
\end{abstract}

Keywords: Savanna, seasonality, species diversity, soil invertebrates, successional stage.

\section{Fauna edáfica em um gradiente vegetacional no Parque Nacional de Sete Cidades}

\begin{abstract}
Resumo
A fisionomia e cobertura vegetal podem mostrar padrões de diversidade e composição da comunidade edáfica, em função da quantidade e qualidade da serapilheira em determinado habitat específico. O presente trabalho teve por objetivo avaliar o efeito do gradiente vegetacional formado por Campo Graminóide (CGR), Cerrado Sensu Stricto (CSS), Cerradão (CRD) e Floresta Estacional Semidecídua (FES) sobre a densidade, diversidade e composição da comunidade da fauna edáfica em duas épocas do ano do Parque Nacional de Sete Cidades (PI). Para amostragem da fauna foram colocadas um total de oito armadilhas do tipo Pit-fall, distanciadas por $10 \mathrm{~m}$, em cada área na parte central de cada sistema, onde permaneceram por sete dias. No período úmido houve uma tendência a aumento do número de indivíduos conforme a complexidade da formação vegetal e o inverso ocorreu no período seco. Verificou-se uma variação ambiental dos fatores climáticos temperatura e umidade conforme a formação vegetal contribuindo para uma distribuição heterogênea da fauna. Apenas no período seco a formação CGR apresentou valor significativamente menor de riqueza média. Em relação às variáveis de diversidade e uniformidade não apresentaram variações drásticas em relação ao gradiente vegetacional estudado. Os grupos dominantes no gradiente vegetacional foram Formicidae, Coleoptera, Aranae, Acari e Collembola, com redução do número de Coleoptera na época seca. Pela análise de componentes principais (ACP) constatou-se maiores diferenças na composição das comunidades entre as formações vegetais para o período chuvoso. Nesta época, as formações vegetais os estádios FES e CRD estiveram associados a uma maior diversidade de invertebrados do que CSS e CGR, demonstrando influência da complexidade vegetacional sobre a comunidade da fauna do solo.
\end{abstract}

Palavras-chave: Cerrado, sazonalidade, diversidade de espécie, invertebrados do solo, estádio sucessional. 


\section{Introduction}

The Sete Cidades National Park (PNSC), created in 1961, is located in the state of Piauí and is one of the most important Conservation Units of the northeastern Savanna, where several phytophysiognomic types can be recognized, composing a vegetation gradient with rural formations, savannas and forests (Matos and Felfili, 2010). The distribution and composition of the PNSC plant communities appear to be related to its own geographical location in areas bordering different floristic domains (Farias Castro, 2003).

These phytophysionomic variations in PNSC have a significant influence on the physical and chemical properties, such as humidity and temperature (Mendes et al., 2012), factors that control the biological functioning in Brazilian Savanna areas (De Carvalho Mendes et al., 2012). Notwithstanding, in spite of the importance of the PNSC, the work done so far is related to botanical (Oliveira et al., 2010), soil chemical and microbiological (Araújo et al., 2017) and geomorphological aspects (IBDF, 1979). In this sense, information on soil invertebrates is extremely relevant, since it can provide data on nutrient cycling and the regulation of primary productivity in these environments (Bustamante et al., 2004).

In general, studies that provide information on the Cerrado soil fauna address the way in which the fauna diversity responds to changes depending on the land use (Gomes et al., 2007; Mussury et al., 2008), since these invertebrates are sensitive to the changes generated by the creation of agroecosystems (Decaens et al., 2004). On the other hand, few studies have evaluated the fauna behavior in soils under preserved environments (Pereira et al., 2013).

There are several factors that may influence the abundance, activity, composition and diversity of the edaphic fauna, such as edaphic factors (soil type, predominant minerals, temperature, $\mathrm{pH}$, organic matter, humidity, texture and structure), those related to vegetation (physiognomy and cover), and historical (especially anthropic but also geological), topographical (physiographic position, inclination) and climatic factors (rainfall, temperature, wind, relative air humidity) (Machado et al., 2015). Works performed by Rantalainen et al. (2004) and Chust et al. (2003) verified that the mosaic of vegetation types or successional stages can show patterns of diversity and composition of the edaphic community, depending on the quantity and quality of litter in a specific habitat.

These invertebrates have a wide variety of size and diameter, which gives them a differentiated hability in their feeding strategy and habitat adaptation (Aquino et al, 2008), which, in turn, can influence the soil processes directly through physical modification of the litter and the soil environment, and indirectly through interactions with the microbial community (Gonzalez et al., 2001). The direct effects on biogeochemical cycling occur through fragmentation, a process known as metabiosis, and by the incorporation of plant debris into the soil, resulting in the creation of new microhabitats, increasing the number of ecological niches and also leading to a complex food chain, allowing the colonization of new species of microorganisms, fauna and even vegetables, thus increasing biodiversity (Correia and Oliveira, 2005).

The objective of this work was to characterize the edaphic fauna throughout a vegetation gradient of the Sete Cidades National Park, in two distinct seasons of the year (summer and winter).

\section{Materials and Methods}

The research was carried out in the Sete Cidades National Park (PNSC) $\left(04^{\circ} 02^{\prime}-08^{\prime} \mathrm{S}\right.$ and $\left.41^{\circ} 40^{\prime}-45^{\prime} \mathrm{W}\right)$, located in the Parnaíba sedimentary basin, in a marginal area of the Savanna domain, between the municipalities of Brasileira and Piracuruca, state of Piauí. The climate is classified as C2w2A'4a', tropical subhumid-humid, megathermal and of small annual thermal amplitude, with an average maximum annual temperature of $28.1^{\circ} \mathrm{C}$ and a minimum of $25.6^{\circ} \mathrm{C}$. The area has a strong seasonality, with a rainy season (December to May) and a dry season (June to November), and average annual rainfall of 1,557.8 $\mathrm{mm}$. The topography is smooth wavy and the altitudes vary from 150 to $290 \mathrm{~m}$. The soil type and texture in the studied areas are presented in Table 1 .

The study was conducted throughout a vegetation gradient formed by the phytophysiognomies: Graminoid Field (GRF), Cerrado Sensu Stricto (CSS), Cerradão (CRD) and Seasonal Semideciduous Forest (SSF). Oliveira et al. 2010, studying the characterization of the vegetation types of PNSC, found a predominantly herbaceous physiognomy in GRF, with robust plants. The CSS and CRD areas showed two extracts, herbaceous-shrub and shrub-tree, with the latter being more scarce in the first area. In turn, the SSF presented a forest and closed aspect, formed by trees around $9 \mathrm{~m}$, with abundance of shrub in the understory and absence of herbaceous extract. The edaphoclimatic properties along the gradient of vegetation are shown in Table 2.

The soil fauna was collected using pitfall traps that consisted of plastic containers ( $10 \mathrm{~cm}$ height, $10 \mathrm{~cm}$ diameter), filled with $2 \%$ formaldehyde containing two drops of detergent, to break the surface tension of the solution to about $1 / 3$ of their volume, being buried in the ground with their opening exactly at soil level. A total of eight traps were placed in each area, which were used as repetition, with an average distance of $8 \mathrm{~m}$ between each in the form of a transect in the central part of each system, where they remained for seven days. To verify a possible seasonal variation in the structure of the macrofauna community, two samplings were performed: one in the rainy season (march 2015) and another in the dry season (september 2015) of the study region. After the collection, the material was packed in identified bottles containing 70\% alcohol for fixing. The organisms were taken to the laboratory and, with the aid of a binocular loupe, they were separated and identified at the level of large taxonomic groups.

Later, comparisons of the communities of the different vegetation formations were made by means of density (number of individuals trap ${ }^{-1}$ day $^{-1}$ ), total richness (number of taxonomic groups present), average richness (average number of taxonomic groups present in each trap). 
Table 1. Soil texture and types in different plant formations.

\begin{tabular}{ccccccc}
\hline $\begin{array}{c}\text { Forest } \\
\text { formation }\end{array}$ & Coarse sand & Fine sand & Silte & Clay & Texture & Soil Types \\
\hline GRF & 14 & 73 & 7 & 6 & Sand & Quartzipsamment \\
CSS & 7 & 71 & 14 & 8 & Sand & Oxissol \\
CRD & 7 & 66 & 16 & 11 & Sand & Oxissol \\
SSF & 5 & 62 & 18 & 15 & Sandy franc & Oxissol \\
\hline
\end{tabular}

GRF - Graminoid Field; CSS - Cerrado Sensu Stricto; CRD - Cerradão; SSF - Semideciduous Seasonal Forest.

Table 2. Edafoclimatic properties of the soil in different vegetation physiognomies in the Sete Cidades National Park, PI.

\begin{tabular}{|c|c|c|c|c|c|c|c|c|c|}
\hline \multirow{2}{*}{ Area } & \multirow{2}{*}{$\begin{array}{c}\text { Tem } \\
{ }^{\circ} \mathrm{C}\end{array}$} & \multirow{2}{*}{$\begin{array}{c}\text { Umi } \\
\%\end{array}$} & \multirow{2}{*}{$\begin{array}{c}\text { pH } \\
\left(\mathbf{H}_{2} \mathrm{O}\right)\end{array}$} & $\mathbf{H}+\mathbf{A l}$ & $\mathrm{Ca}+\mathrm{Mg}$ & $\mathbf{K}$ & \multirow{2}{*}{$\begin{array}{c}P \\
\left(\mathrm{mg} \mathrm{dm}-{ }^{3}\right)\end{array}$} & \multirow{2}{*}{$\begin{array}{c}\text { TOC } \\
\left(\mathrm{g} \mathrm{kg}^{-1}\right)\end{array}$} & \multirow{2}{*}{$\begin{array}{c}\mathrm{N} \\
\left(\text { dagkg }^{-1}\right)\end{array}$} \\
\hline & & & & \multicolumn{3}{|c|}{...........(cmolc dm $\left.^{-3}\right)$} & & & \\
\hline \multicolumn{10}{|c|}{ Rainy season } \\
\hline GRF & $28.3 \mathrm{a}$ & $7.10 \mathrm{~b}$ & $4.95 \mathrm{a}$ & $1.52 \mathrm{c}$ & $0.14 \mathrm{c}$ & $1.33 \mathrm{~b}$ & $3.57 \mathrm{~b}$ & $4.46 \mathrm{c}$ & $0.02 \mathrm{~b}$ \\
\hline CSS & $25.7 \mathrm{~b}$ & $7.25 \mathrm{~b}$ & $4.85 \mathrm{a}$ & $3.33 \mathrm{~b}$ & $0.45 \mathrm{~b}$ & $1.86 \mathrm{~b}$ & $4.87 \mathrm{a}$ & $8.12 \mathrm{~b}$ & $0.03 \mathrm{~b}$ \\
\hline CRD & $25.5 \mathrm{~b}$ & $9.18 \mathrm{a}$ & $4.79 \mathrm{a}$ & $4.86 \mathrm{a}$ & $0.42 \mathrm{~b}$ & $1.80 \mathrm{~b}$ & $4.81 \mathrm{a}$ & $8.84 \mathrm{~b}$ & $0.03 \mathrm{~b}$ \\
\hline SSF & $25.4 \mathrm{~b}$ & $8.85 \mathrm{a}$ & $4.83 \mathrm{a}$ & $3.71 \mathrm{c}$ & $0.76 \mathrm{a}$ & $2.70 \mathrm{a}$ & $4.71 \mathrm{a}$ & $18.45 \mathrm{a}$ & $0.08 \mathrm{a}$ \\
\hline \multicolumn{10}{|c|}{ Dry season } \\
\hline CG & $36.4 \mathrm{a}$ & $0.20 \mathrm{~b}$ & $4.81 \mathrm{a}$ & $1.35 \mathrm{c}$ & $0.26 \mathrm{c}$ & $1.13 \mathrm{c}$ & $1.89 \mathrm{~b}$ & $4.52 \mathrm{c}$ & $0.02 \mathrm{~b}$ \\
\hline CSS & $33.2 \mathrm{~b}$ & $0.52 \mathrm{~b}$ & $3.89 \mathrm{~b}$ & $2.60 \mathrm{~b}$ & $0.53 \mathrm{~b}$ & $1.59 \mathrm{~b}$ & $3.01 \mathrm{a}$ & $7.50 \mathrm{~b}$ & $0.03 \mathrm{~b}$ \\
\hline CD & $31.9 \mathrm{c}$ & $0.62 \mathrm{~b}$ & $4.26 \mathrm{~b}$ & $3.56 \mathrm{a}$ & $0.47 \mathrm{~b}$ & $1.76 \mathrm{~b}$ & $3.04 \mathrm{a}$ & $8.57 \mathrm{~b}$ & $0.03 \mathrm{~b}$ \\
\hline SSF & $32.6 \mathrm{c}$ & $1.56 \mathrm{a}$ & $4.67 \mathrm{a}$ & $3.23 \mathrm{a}$ & $0.98 \mathrm{a}$ & $4.65 \mathrm{a}$ & $3.67 \mathrm{a}$ & $17.33 \mathrm{a}$ & $0.10 \mathrm{a}$ \\
\hline
\end{tabular}

GRF - Graminoid Field; CSS - Cerrado Sensu Stricto; CRD - Cerradão; SSF - Semideciduous Seasonal Forest. Means followed by the same letter in the column do not differ from each other by the Tukey test at $5 \%$ probability. Tem $=$ Temperature; $\mathrm{Umi}=$ Humidity; $\mathrm{TOC}=$ Total organic carbon .

Shannon diversity index, a suitable index used in soil ecology, is able to indicate higher values to the rare species present in the community, $(\mathrm{H}=-\Sigma$ pi $x \log 2 \mathrm{pi})$, where pi is the proportion of individuals belonging to the nth family. Pielou equability index ( $\mathrm{H} \log \mathrm{S}-1)$, where $\mathrm{H}$ corresponds to the Shannon index, $\mathrm{n}$ is the total number of individuals in the community and $\mathrm{S}$ is the total number of species found in each management system. These variables present an adequate response pattern for comparisons of different environmental situations.

The results of the number of individuals collected and richness edaphic fauna groups were submitted to analysis of variance and the comparison of means between each system was done by means of the application of Tukey test at 5\%, through $\mathrm{R}$ software (R Core Team, 2016). A multivariate analysis of principal components was carried out using the CANOCO (version 5) (Ter Braak and Smilauer, 2012), between taxonomic groups and soil management systems.

\section{Results and Discussion}

The highest abundance of edaphic fauna was recorded in SSF areas, with 18.28 individuals trap ${ }^{-1}$ day $^{-1}$, and in GRF, with 21.3 individuals trap ${ }^{-1}$ day $^{-1}$, in rainy and dry seasons, respectively (Table 3 ). In the rainy season, there was a tendency to increase the number of individuals according to the complexity of the vegetation formation. In turn, in the dry season, this situation has reversed. In general, higher densities of individuals of the soil fauna occur due to the greater presence of ants, which are social insects, and tend to be sampled in aggregates with a high number of individuals (Menezes et al., 2009).

By analyzing the mean standard error of the number of individuals, a great environmental heterogeneity was observed, which showed an effect of seasonality in this study. Thus, in the wet season, the standard error in all systems was shown to be close, ranging from 22 to $26 \%$ (Figure 1). However, there was a tendency to increase the standard error in the dry season, which in CRD and GRF represented 40 and $38 \%$ of the average, respectively, well above the CRD and SSF groups that present values of this variable of 27 and $32 \%$ and shows that certain groups of invertebrates were found in only a few traps. This increase in spatial variability in forest systems probably indicates a seasonal change in the availability of the resources used by the fauna, which causes high density due to more favorable abiotic factors (temperature, luminosity and humidity), wich vary according to seasons of the year (seasonality) and different types of habitats and microhabitats (fields and forests), as also observed by Menezes et al. (2009) and Yankelevich et al. (2006).

The results of this research showed that the vegetation gradient of the studied areas resulted in an environmental variation of the climatic factors temperature and humidity, contributing to this observed heterogeneous distribution. There was an increase of more than $3{ }^{\circ} \mathrm{C}$ in the temperature of GRF in relation to the other vegetation formations, and humidity near zero in the dry season (Table 2 ). This occurred due to the sandy texture associated with this feature, which favors easier water loss. In addition, GRF shows 
Table 3. Number individuals with respective standard errors, total richness and average richness of the soil fauna under different forest formations.

\begin{tabular}{|c|c|c|c|c|c|}
\hline $\begin{array}{c}\text { Forest } \\
\text { formations }\end{array}$ & $\begin{array}{l}\text { Ind. trap }{ }^{-1} \text { day }^{-1} \pm \\
\text { Default error }\end{array}$ & Richness & Average eichness & Index Shannon & Index Pielou \\
\hline \multicolumn{6}{|c|}{ Rainy season } \\
\hline GRF & $11.96 b \pm 3.17$ & $18 \mathrm{a}$ & $10.6 \mathrm{a}$ & 2.42 & 0.58 \\
\hline CSS & $12.00 \mathrm{~b} \pm 2.66$ & $20 \mathrm{a}$ & $10.0 \mathrm{a}$ & 2.51 & 0.58 \\
\hline CRD & $14.05 \mathrm{ab} \pm 3.43$ & $18 \mathrm{a}$ & $10.2 \mathrm{a}$ & 2.66 & 0.64 \\
\hline SSF & $18.28 \mathrm{a} \pm 4.63$ & $18 \mathrm{a}$ & $10.0 \mathrm{a}$ & 2.26 & 0.54 \\
\hline \multicolumn{6}{|c|}{ Dry season } \\
\hline GRF & $21.42 \mathrm{a} \pm 8.30$ & $14 \mathrm{a}$ & $6.63 \mathrm{~b}$ & 2.16 & 0.58 \\
\hline CSS & $10.40 \mathrm{~b} \pm 2.96$ & $15 \mathrm{a}$ & $8.37 \mathrm{ab}$ & 2.41 & 0.62 \\
\hline CRD & $14.61 \mathrm{ab} \pm 5.90$ & $15 \mathrm{a}$ & $8.63 \mathrm{a}$ & 2.19 & 0.59 \\
\hline SSF & $8.88 \mathrm{~b} \pm 2.76$ & $16 \mathrm{a}$ & $8.63 \mathrm{a}$ & 2.62 & 0.66 \\
\hline
\end{tabular}

Means followed by the same letter in the column did not differ statistically from each other by the Tukey's test $(\mathrm{P}<0.05)$. GRF - Graminoid Field; CSS - Cerrado Sensu Stricto; CRD - Cerradão; SSF - Semideciduous Seasonal Forest.

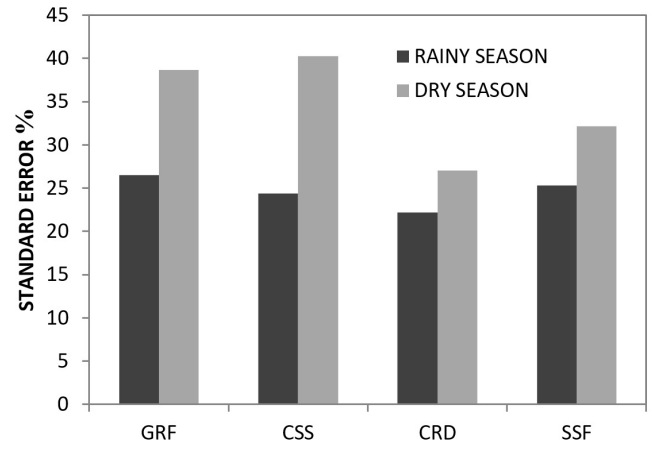

Figure 1. Seasonal variation standard error of the mean density of soil macrofauna under different forest formations. GRF - Graminoid Field; CSS - Cerrado Senso Stricto; CRD - Cerradão; SSF -Semideciduous Seasonal Forest.

a vegetation with a very open physiognomy composed almost entirely of caespitose grasses (Oliveira et al., 2010) that little prevent the direct incidence of solar radiation, contributing to the increase of soil temperature.

Regarding the diversity variables, it was observed that GRF showed a significantly lower value of average richnessonly in the dry season. Regarding the Shannon's index and the Pielou index, which represents the uniformity of the distribution of the number of individuals in the different groups in each area, no drastic variations were shown in relation to the studied vegetation gradient.

Several studies have shown a pattern of increase of these variables as a function of successional advancement or environmental preservation as compared with anthropic lands (Tews et al., 2004; Moço et al., 2005; Gomes et al., 2007; Mussury et al., 2008; Machado et al., 2015). These authors concluded that the structural complexity of the vegetation in terms of diversity, led to higher deposition and better quality of litter, providing more favorable conditions of food resources, shelter and reproduction. Therefore, any intervention, be it anthropogenic or natural, can potentially affect the dynamics of the soil fauna and, consequently, the ecological functions in which it is involved.

Therefore, although there is a vegetative gradient in these areas, the absence of major differences between the edaphic fauna variables studied in these different phytophysiognomies can be attributed to the fact that these vegetation formations are located in a permanent preservation area without any anthropic action.

In general, the groups Acari, Aranae, Collembolla, Coleoptera, Diptera and Formicidae were present in good proportions in all vegetation formations and in both periods (Table 4). According to Brown (1997), the individuals or species of these orders constitute the most important bioindicators of the soil fauna, with the exception of the individuals of the group Aranae.

The groups Formicidae and Coleoptera, which present saprophagous and predatory organisms - in addition to individuals that simultaneously exercise these two functions -, had the highest concentrations in the rainy season in GRF, CSS, CRD and SSF, respectively. However in the dry period, the Coleoptera presented a drastic reduction. A study carried out by Nunes et al. (2008) showed that these organisms represented about $40 \%$ of the total of individuals in a forest under caatinga in the rainy season, being favored by dense litter. In turn, Martins et al. (2009) found that more simplified environments favor the reduction of species of this group, mainly due to the alteration of the microclimate, since temperature and soil humidity are factors that regulate the distribution of these insects.

Seasonality also influenced the presence of coleopteran larvae, which occurred only in the rainy season, because the larval stage of this insect is found only in the period of good soil moisture (Assis Junior, 2000). In a previous study, Araújo et al. (2010) found, in the top layer of the soil from Caatinga forest, an abundance of $14 \%$ of insects, in larval stage, during the rainy season and only $3.8 \%$ of insects under water stress conditions. 
Table 4. Relative distribuition (\%) of soil fauna groups under differents forest formations.

\begin{tabular}{|c|c|c|c|c|}
\hline \multirow{2}{*}{ Grupos } & GRF & CSS & CRD & SSF \\
\hline & \multicolumn{4}{|c|}{ Rainy season } \\
\hline Acari & 7.14 & 14.43 & 5.24 & 2.30 \\
\hline Araneae & 10.60 & 9.52 & 6.1 & 1.16 \\
\hline Collembola & 13.59 & 20.47 & 17.54 & 3.32 \\
\hline Coleoptera & 7.56 & 6.70 & 29.14 & 58.35 \\
\hline Díptera & 3.88 & 5.65 & 6.25 & 7.22 \\
\hline Formicidae & 44.88 & 33.00 & 24.02 & 14.42 \\
\hline Larva de coleoptera & 0.22 & 0.60 & 2.41 & 5.27 \\
\hline Orthoptera & 3.14 & 1.49 & 2.92 & 0.88 \\
\hline \multirow[t]{2}{*}{ Pseudoscorpionidae } & 3.51 & 2.53 & 0.80 & 1.05 \\
\hline & \multicolumn{4}{|c|}{ Dry season } \\
\hline Outros & 8.62 & 7.10 & 8.50 & 7.01 \\
\hline Acari & 12.08 & 5.35 & 16.39 & 19.36 \\
\hline Araneae & 4.35 & 12.30 & 21.46 & 11.44 \\
\hline Collembola & 31.49 & 47.09 & 31.08 & 34.59 \\
\hline Coleoptera & 0.66 & 3.42 & 4.61 & 4.05 \\
\hline Díptera & 0.58 & 2.14 & 1.81 & 7.04 \\
\hline Formicidae & 30.61 & 23.31 & 17.44 & 11.26 \\
\hline Isoptera & 9.21 & 0.96 & 1.20 & 0.70 \\
\hline Pseudoscorpionidae & 0.29 & 1.24 & 1.35 & 1.41 \\
\hline Outros & 10.73 & 4.19 & 4.66 & 10.15 \\
\hline
\end{tabular}

GRF - Graminoid Field; CSS - Cerrado Sensu Stricto; CRD - Cerradão; SSF - Semideciduous Seasonal Forest.

On the other hand, the presence of Formicidae under adverse conditions (rainy and dry conditions) is due to the fact that this group comprises one third of the total biomass of insects found in Brazilian forests, or because they are important for cycling of nutrients and forest regeneration (Leal, 2004). This group also dominates the soil macrofauna in others areas under tropical savanna, such as Colombian Llanos (Decaëns et al., 2004) and Brazilian Cerrado (Marchão et al., 2009), as well as arid ecosystems from Brazil (Araújo et al., 2010; Vasconcellos et al., 2010).

Another highlight may be given to the microfauna group Collembola, being present in all vegetation formations, mainly during the dry period. These organisms have a strong interaction with the soil due to dietary habits, participating in the nutrient cycling, either by decomposing organic matter or by feeding fungi and bacteria (Bellini and Zeppelini, 2009). As a result, some studies have shown that preserved areas provide better edaphic conditions and are able to withstand greater abundance and diversity of Collembola in comparison to areas that have suffered greater anthropic interference (Maunsell et al., 2013; Cassagne et al., 2006).

With the principal component analysis (PCA) for the two periods (Figure 2), it is possible to separate the studied units by their differences in the composition of the edaphic macrofauna community.

In the rainy season, this analysis shows the predominance of Formicidae, Isoptera, Homoptera and Orthoptera in the GRF macrofauna community; of Acari, Collembola,
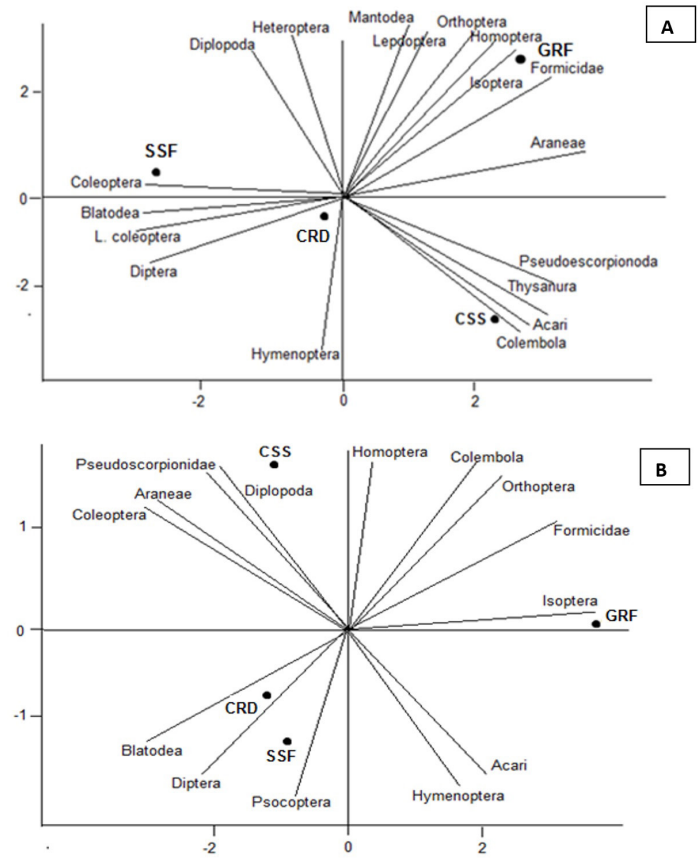

Figure 2. Analysis of Principal Component Analysis (PCA) of the invertebrate macrofauna of the soil under different forest formations for the rainy season (A) and dry (B). GRF - Graminoid Field; CSS - Cerrado Senso Stricto; CRD - Cerradão; SSF - Semideciduous Seasonal Forest. 
Thysanura and Pseudoscorpionidae and Heteroptera in the CSS macrofauna; while showing SFMS and SFAS more related to the groups Coleoptera, Blatodea, Coleoptera larvae, Diptera and Hymenoptera. It was also verified the presence of some groups such as Aranae, Heteroptera and Diplopoda that did not show predominance over any vegetation formation. Principal component analysis (PCA) for the dry period showed greater proximity to the SSF and CRD units, which were related to Blatodea, Diptera and Psocoptera. The GRF and CSS were more distant from the previous ones and, among them: GRF was related to the group Isoptera, and CSS to the groups Diplopoda and Pseudoscorpionidae. In this period, the groups Acari, Collembola, Hymenoptera and Orthoptera were not associated to any phytophysiognomy.

Although this study was carried out in an area with different phytophysiognomies that range from herbaceous formation to a forest formed by a closed arboreal extract, the greater presence of litter was not determinant for the dominance of certain groups in these vegetation formations. Therefore, the presence of saprophagous and predatory groups was observed in all areas, in addition to other groups that were not closely associated with a given area. As the PNSC is located in an area of permanent preservation, it is possible that the absence of anthropic action provides an environment that favors the colonization of the edaphic fauna with similar richness, diversity and uniformity.

\section{Conclusions}

The macrofauna community was not affected by the increase of the vegetation diversity, not showing a progressive increase of the variables analyzed in relation to the successional stages.

Seasonality had an effect on density and average richness, not altering the total fauna diversity in the different systems.

The dominant groups in the vegetation gradient were Formicidae, Coleoptera, Aranae, Acari and Collembola, with reduction of the number of Coleoptera in the dry season. In the more complex formations, a greater diversity of invertebrates was found.

\section{Acknowledgements}

The authors thank "Fundação de Amparo à Pesquisa no Estado do Piauí" (FAPEPI) and "Conselho Nacional de Desenvolvimento Científico e Tecnológico" (CNPq) for financial support to this project trought of PRONEX (FAPEPI/CNPq).

\section{References}

AQUINO, A.M., CORREIA, M.E.F. and ALVES, M.V., 2008. Diversidade da macrofauna edáfica no Brasil. In: F.M.S. MOREIRA, J.O. SIQUEIRA and L. BRUSSAARD, eds. Biodiversidade do solo em ecossistemas brasileiros. Lavras: Universidade Federal de Lavras, pp. 143-170.
ARAÚJO, A.S.F., MAGALHÃES, L.B., SANTOS, V.M., NUNES, L.A.P.L. and DIAS, C.T.S., 2017. Biological properties of disturbed and undisturbed Cerrado sensu stricto from Northeast Brazil. Brazilian Journal of Biology = Revista Brasileira de Biologia, vol. 77, no. 1, pp. 16-21. http://dx.doi.org/10.1590/1519-6984.06715. PMid:27382993.

ARAÚJO, V.F.P., BANDEIRA, A.G. and VASCONCELLOS, A., 2010. Abundance and stratification of soil macroarthropods in a Caatinga Forest in Northeast Brazil. Brazilian Journal of Biology = Revista Brasileira de Biologia, vol. 70, no. 3, (suppl.), pp. 737-746. http://dx.doi.org/10.1590/S1519-69842010000400006. PMid:21085780.

ASSIS JÚNIOR, S.L., 2000. Sistemas agroflorestais versus Monoculturas: coleóptera, scarabaeidae e microbiota do solo como bioindicadores de sustentabilidade. Viçosa: Universidade Federal de Viçosa, 70 p. Tese de Doutorado em Engenharia Florestal.

BELLINI, B.C. and ZEPPELINI, D., 2009. Registros da fauna de Collembola (Arthropoda, Hexapoda) no Estado da Paraíba, Brasil. Revista Brasileira de Entomologia, vol. 53, no. 3, pp. 386-390. http://dx.doi.org/10.1590/S0085-56262009000300012.

BROWN, K.S., 1997. Insetos como rápidos e sensíveis indicadores de uso sustentável de recursos naturais. In: H.L. MARTOS and N.B. MAIA, eds. Indicadores ambientais. Sorocaba: PUC / Shell Brasil, pp. 143-151.

BUSTAMANTE, M.M.C., NARDOTO, G.B. and MARTINELLI, L.A., 2004. Aspectos comparativos del ciclaje de nutrientes entre bosques amazônicos de terra-firme y sabanas tropicales (cerrado brasileiro). In: H.M. Cabrera, ed. Fisiologia ecologica en plantas: mecanismos y respuestas a estres en los ecossistemas, Valparaiso: Ediciones Universitarias de Valparaiso, Pontificia Universidad Catolica de Valparaiso, pp. 189-205.

CASSAGNE, N., GAUQUELIN, T., BAL-SERIN, M.C. and GERS, C., 2006. Endemic Collembola, privileged bioindicators of forest management. Pedobiologia, vol. 50, no. 2, pp. 127-134. http://dx.doi.org/10.1016/j.pedobi.2005.10.002.

CHUST, G., PRETUS, J.L., DUCROT, D., BEDÒS, A. and DEHARVENG, L., 2003. Response of soil fauna to landscape heterogeneity: Determining optimal scales for biodiversity modeling. Conservation Biology, vol. 17, no. 6, pp. 1712-1723. http://dx.doi.org/10.1111/j.1523-1739.2003.00564.x.

CORREIA, M.E.F. and OLIVEIRA, L.C.M., 2005. Importância da fauna para a ciclagem de nutrientes. In: A. AQUINO and R.L. ASSIS eds. Processos biológicos no sistema solo-planta: ferramentas para a agricultura sustentável. Brasília: Embrapa Informação Tecnológica; Seropédica: Embrapa Agrobiologia, pp. 77-99.

DE CARVALHO MENDES, I., FERNANDES, M.F., CHAER, G.M. and BUENO DOS REIS JUNIOR, F., 2012. Biological functioning of Brazilian Cerrado soils under different vegetation types. Plant and Soil, vol. 359, no. 1, pp. 183-195. http://dx.doi. org/10.1007/s11104-012-1195-6.

DECAËNS, T., JIMÉNEZ, J.J., BARROS, E., CHAUVEL, A., BLANCHART, E., FRAGOSO, C. and LAVELLE, P., 2004. Soil macrofaunal communities in permanent pastures derived from tropical forest or savanna. Agriculture, Ecosystems \& Environment, vol. 103, no. 2, pp. 301-312. http://dx.doi.org/10.1016/j.agee.2003.12.005.

FARIAS CASTRO, A.A.J., 2003. Survey of the vegetation in the state of Piauí. In: T. GAISER, M. KROL, H. FRISCHKORN and J.C. ARAÚJO, eds. Global change and regional impacts: water availability and vulnerability of ecosystems and society 
in the semiarid northeast of Brazil. New York: Springer-Verlag, pp. 117-123. http://dx.doi.org/10.1007/978-3-642-55659-3_9.

GOMES, A.A., MUSSURY, R.M., SCALON, S.P.Q., WATTHIER, F., CUNHA, K.A.A. and SCALON FILHO, H., 2007. Avaliação do impacto da fragmentação de florestas nativas sobre a mesofauna edáfica na região de Dourados, MS. Ciência e Agrotecnologia, vol. 31, no. 3, pp. 612-618. http://dx.doi.org/10.1590/S141370542007000300003 .

GONZÁLEZ, G., LEY, R.E., SCHMIDT, S.K., ZOU, X. and SEASTEDT, T.R., 2001. Soil ecological interactions: comparisons between tropical and subalpine forest. Oecologia, vol. 128, no. 4, pp. 549-556. http://dx.doi.org/10.1007/s004420100685. PMid:28547400.

INSTITUTO BRASILEIRO DE DESENVOLVIMENTO FLORESTAL - IBDF, 1979. Plano de manejo: Parque Nacional de Sete Cidades. Brasília: IBDF/FBCN.

LEAL, I.R., 2004. Dispersão de sementes por formigas na caatinga. In: I.R. LEAL, M. TABARELLI and J.M.C. SILVA, eds. Ecologia e conservação da Caatinga: uma introdução ao desafio. Recife: EDUFPE, pp. 593- 624

MACHADO, D.L., PEREIRA, M.G., CORREIA, M.E.F., DINIZ, A.R. and MENEZES, C.E.B., 2015. Fauna edáfica na dinâmica sucessional da mata atlântica em floresta estacional semidecidual na bacia do rio Paraíba do Sul - RJ. Ciência Florestal, vol. 25, no. 1, pp. 91-106. http://dx.doi.org/10.5902/1980509817466.

MARCHÃO, R.L., LAVELLE, P., CELINI, L., BALBINO, L.C., VILELA, L. and BECQUER, T., 2009. Soil macrofauna under integrated crop-livestock systems in a Brazilian Cerrado Ferralsol. Pesquisa Agropecuária Brasileira, vol. 44, no. 8, pp. 1011-1020. http://dx.doi.org/10.1590/S0100-204X2009000800033.

MARTINS, I.C.F., CIVIDANES, F.J., BARBOSA, J.C., ARAÚJO, E.S. and HADDAD, G.Q., 2009. Análise de fauna e flutuação populacional de Carabidae e Staphylinidae (Coleoptera) em sistemas de plantio direto e convencional. Revista Brasileira de Entomologia, vol. 53, no. 3, pp. 432-443. http://dx.doi.org/10.1590/ S0085-56262009000300019.

MATOS, M.Q. and FELFILI, J.M., 2010. Florística, fitossociologia e diversidade da vegetação arbórea nas matas de galeria do Parque Nacional de Sete Cidades (PNSC), Piauí, Brasil. Acta Botanica Brasílica, vol. 24, no. 2, pp. 483-496. http://dx.doi.org/10.1590/ S0102-33062010000200019.

MAUNSELL, S.C., KITCHING, R.L., GREENSLADE, P., NAKAMURA, A. and BURWELL, C.J., 2013. Springtail (Collembola) assemblages along an elevational gradient in Australian subtropical rainforest. Australian Journal of Entomology, vol. 52, no. 1, pp. 114-124. http://dx.doi.org/10.1111/aen.12012.

MENDES, M.R.A., MUNHOZ, C.B.R., SILVA JÚNIOR, M.C. and CASTRO, A.A.J.F., 2012. Relação entre a vegetação e as propriedades do solo em áreas de campo limpo úmido no Parque Nacional de Sete Cidades, Piauí, Brasil. Rodriguésia, vol. 63, no. 4, pp. 971-984. http://dx.doi.org/10.1590/S2175-78602012000400014.

MENEZES, C.E.G., CORREIA, M.E.F., PEREIRA, M.G., BATISTA, I., RODRIGUES, K.M., COUTO, W.H., ANJOS, L.H.C. and OLIVEIRA, I.P., 2009. Macrofauna edáfica em estádios sucessionais de Floresta estacional semidecidual e pastagem Mista em Pinheiral (RJ). Revista Brasileira de Ciência do Solo, vol. 33, no. 6, pp. 1647-1656. http://dx.doi.org/10.1590/ S0100-06832009000600013.

MOÇO, M.K., GAMA-RODRIGUES, E.F., GAMA RODRIGUES, A.C. and CORREIA, M.E.F., 2005. Caracterização da fauna edáfica em diferentes coberturas vegetais na região Norte Fluminense. Revista Brasileira de Ciência do Solo, vol. 29, no. 4, pp. 555-564. http://dx.doi.org/10.1590/S0100-06832005000400008.

MUSSURY, R.M., SCALON, S.P.Q., GOMES, A.A., BATISTA, M.R. and SCALON FILHO, H., 2008. Flutuação populacional da mesofauna em fragmentos de mata na região de Dourados, MS. Ciência e Agrotecnologia, vol. 32, no. 2, pp. 645-650. http:// dx.doi.org/10.1590/S1413-70542008000200047.

NUNES, L.A.P.L., ARAUJO FILHO, J.A. and MENEZES, R.I.Q., 2008. Recolonização da fauna edáfica em áreas de caatinga submetidas a queimadas. Caatinga, vol. 21, no. 1, pp. 214-220. http://dx.doi.org/10.5380/rsa.v10i1.13162.

OLIVEIRA, M.E., CASTRO, A.A.J.F. and MARTINS, F.R., 2010. Classificação e caracterização dos tipos vegetacionais do Parque Nacional de Sete Cidades, Piaú, Brasil. In: A.A.J.F. CASTRO, N.M.C.F. CASTRO and C. ARZABE, eds. Biodiversidade e Ecótonos da Região Setentrional do Piauí. Teresina: Editora Gráfica da UFPI, pp. 66-89.

PEREIRA, G.H.A., PEREIRA, M.G., ANJOS, L.H.C., AMORIM, T.A. and MENEZES, C.E.G., 2013. Decomposição da serrapilheira, diversidade e funcionalidade de invertebrados do solo em um fragmento de Floresta Atlântica. Bioscience Journal, vol. 29, no. 5, pp. 1317-1327.

R CORE TEAM, 2016. R: A Language and Environment for Statistical Computing. R Foundation for Statistical Computing. Vienna, Austria.

RANTALAINEN, M.L., KONTIOLA, L., HAIMI, J., FRITZE, H. and SETÄLA, H., 2004. Influence of resource quality on the composition of soil decomposer community in fragmented and continuous habitat. Soil Biology \& Biochemistry, vol. 36, no. 12, pp. 1983-1996. http://dx.doi.org/10.1016/j.soilbio.2004.05.017.

TER BRAAK, C.J.F. and SMILAUER, P., 2012. CANOCO Reference Manual and User's Guide: Software for Ordination (Version 5.0). Ithaca, NY: Microcomputer Power.

TEWS, J., BROSE, U., GRIMM, U., TIELBÖRGER, K., WICHMANN, M.C., SCHAWGER, M. and JELTSCH, F., 2004. Animal species diversity driven by habitat heterogeneity/ diversity: The importance of keystone structures. Journal of Biogeography, v. 31, no. 1, pp. 79-92. http://dx.doi.10.1046/j.03050270.2003.00994.x.

VASCONCELLOS, A., BANDEIRA, A.G., MOURA, F.M.S., ARAÚJO, V.F.P., GUSMÃO, M.A.B. and CONSTANTINO, R., 2010. Termite assemblages in three habitats under different disturbance regimes in the semi-arid Caatinga of NE Brazil. Journal of Arid Environments, vol. 74, no. 2, pp. 298-302. http:// dx.doi.org/10.1016/j.jaridenv.2009.07.007.

YANKELEVICH, S.N., FRAGOSO, C., NEWTON, A.C., RUSSELL, G. and HEAL, O.W., 2006. Spatial patchiness of litter, nutrients and macroinvertebrates during secondary sucession in a Tropical Montane Cloud Forest in Mexico. Plant Soil, v. 286, no. 1, pp. 123-139. http://dx. doi.org./10.1007/s11104-006-9031-5. 